\title{
Teaching Video NeuroImage: ECG-Gated 4-D CT Angiography Can Detect Aortic Plaque Mobility in Cryptogenic Stroke
}

Mikito Saito, MD, Hiroyuki Kawano, MD, PhD, Masamichi Koyanagi, MSc, Miho Gomyo, MD, PhD, Kenichi Yokoyama, MD, PhD, and Teruyuki Hirano, MD, PhD

Neurology ${ }^{\circledR}$ 2021;97:e431-e432. doi:10.1212/WNL.0000000000012054

Figure Radiologic Findings
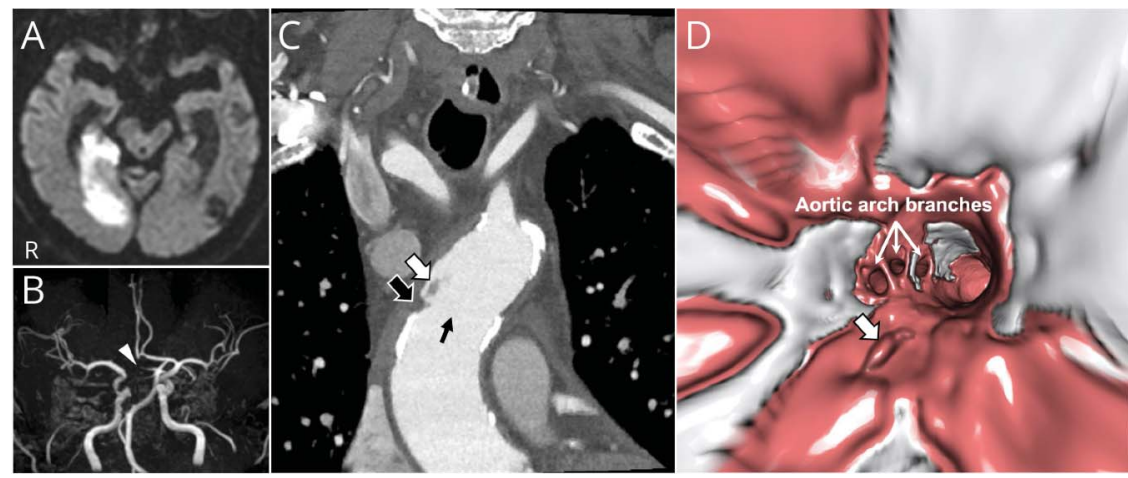

(A) Noncontrasted brain MRI diffusion-weighted imaging sequence shows a high-intensity signal in the right posterior cerebral artery (PCA) region. (B) Noncontrasted brain magnetic resonance angiography sequence shows the right PCA occlusion (arrowhead). (C) Coronal view of ECG-gated 4-D CT angiography shows the plaque (black arrow) with the superimposed component (white arrow). (D) Virtual angioscopy from the viewpoint of the ascending aorta (small arrow in C) shows the superimposed component (white arrow).

An 80-year-old man developed an acute ischemic stroke and right posterior cerebral artery (PCA) occlusion (figure, A and B). Cardiac and carotid artery ultrasound examinations and 24hour ECG monitoring did not identify any embolic sources. ECG-gated 4-D CT angiography (CTA) showed a noncalcified plaque with a superimposed mobile component on the ascending aorta (figure, C, and video 1). Virtual angioscopy using the datasets from ECG-gated 4-D CTA showed seaweed-like mobile component in the 3-D view (figure, D, and video 1). This was diagnosed as aortogenic embolism. The antithrombotic therapy was changed from clopidogrel to warfarin with an international normalized ratio of 2.0-3.0, and low-density lipoprotein cholesterol levels were controlled to less than $70 \mathrm{mg} / \mathrm{dL}$ by rosuvastatin.

Aortic plaque is one of the causes of cryptogenic stroke. ${ }^{1}$ ECG-gated 4-D CTA can evaluate aortic plaque mobility in the ascending aortic arch and the whole aortic arch. ECG-gated synchronization reduces motion artefact compared to non-ECG-gated CT and improves the assessment of plaque morphology and mobility. ${ }^{2}$ In addition, the virtual angioscopic view, which is an image processing technique to provide endoluminal views of blood vessels, ${ }^{3}$ can show plaque mobility in 3-D and make it easy to understand the positional relationships between the plaque and the aortic arch branches.

\section{Correspondence}

Dr. Kawano

hkawano@ks.kyorin-u.ac.jp

\section{MORE ONLINE}

\section{$\checkmark$ Video}

\section{Teaching slides}

links.lww.com/WNL/

B371

From the Departments of Stroke and Cerebrovascular Medicine (M.S., H.K., T.H.) and Radiology (M.G., K.Y.), Kyorin University Faculty of Medicine; and Radiology Department (M.K.), Kyorin University Hospital, Tokyo, Japan.

Go to Neurology.org/N for full disclosures. 


\section{Study Funding}

No targeted funding reported.

\section{Disclosure}

The authors report no disclosures relevant to the manuscript. Go to Neurology.org/N for full disclosures.

\begin{tabular}{lll}
\hline Appendix & Authors & \\
\hline Name & Location & Contribution \\
\hline $\begin{array}{l}\text { Mikito Saito, } \\
\text { MD }\end{array}$ & $\begin{array}{l}\text { Kyorin University, } \\
\text { Tokyo, Japan }\end{array}$ & $\begin{array}{l}\text { Drafting of the manuscript, concept, } \\
\text { design, and critical revision of } \\
\text { manuscript for intellectual content, } \\
\text { major role in the acquisition of data }\end{array}$ \\
\hline $\begin{array}{l}\text { Hiroyuki } \\
\text { Kawano, MD, }\end{array}$ & $\begin{array}{l}\text { Kyorin University, } \\
\text { Tokyo, Japan }\end{array}$ & $\begin{array}{l}\text { Drafting of the manuscript, critical } \\
\text { revision of the manuscript for } \\
\text { intellectual content }\end{array}$ \\
\hline $\begin{array}{l}\text { Masamichi } \\
\text { Koyanagi, } \\
\text { MSc }\end{array}$ & $\begin{array}{l}\text { Kyorin University } \\
\text { Hospital, Tokyo, } \\
\text { Japan }\end{array}$ & \begin{tabular}{l} 
Major role in the acquisition of data \\
\hline
\end{tabular} \\
\hline
\end{tabular}

Appendix (continued)

\begin{tabular}{lll}
\hline Name & Location & Contribution \\
\hline $\begin{array}{l}\text { Miho Gomyo, } \\
\text { MD, PhD }\end{array}$ & $\begin{array}{l}\text { Kyorin University, } \\
\text { Tokyo, Japan }\end{array}$ & $\begin{array}{l}\text { Major role in the acquisition of data, } \\
\text { critical revision of the manuscript for } \\
\text { intellectual content }\end{array}$ \\
\hline $\begin{array}{l}\text { Kenichi } \\
\text { Yokoyama, } \\
\text { MD, PhD }\end{array}$ & $\begin{array}{l}\text { Kyorin University, } \\
\text { Tokyo, Japan }\end{array}$ & $\begin{array}{l}\text { Critical revision of the manuscript for } \\
\text { intellectual content }\end{array}$ \\
$\begin{array}{l}\text { Teruyuki } \\
\text { Hirano, MD, } \\
\text { PhD }\end{array}$ & $\begin{array}{l}\text { Kyorin University, } \\
\text { Tokyo, Japan }\end{array}$ & $\begin{array}{l}\text { Critical revision of the manuscript for } \\
\text { intellectual content, study } \\
\text { supervision, final approval of the } \\
\text { article }\end{array}$ \\
\hline
\end{tabular}

\section{References}

1. $\quad$ Saver JL. Cryptogenic stroke. N Engl J Med. 2016;374(24):2065-2074.

2. Schertler T, Glücker T, Wildermuth S, Jungius KP, Marincek B, Boehm T. Comparison of retrospectively ECG-gated and nongated MDCT of the chest in an emergency setting regarding workflow, image quality, and diagnostic certainty. Emerg Radiol. 2005(1-2);12:19-29.

3. Louis N, Desgranges P, Kobeiter H, Kirsch M, Becquemin JP. Virtual angioscopy and 3-dimensional navigation findings of the aortic arch after vascular surgery. Circulation. 2009;119(7):1052-1055. 


\section{Neurology}

\section{Teaching Video NeuroImage: ECG-Gated 4-D CT Angiography Can Detect Aortic Plaque Mobility in Cryptogenic Stroke}

Mikito Saito, Hiroyuki Kawano, Masamichi Koyanagi, et al.

Neurology 2021;97;e431-e432 Published Online before print April 26, 2021

DOI 10.1212/WNL.0000000000012054

This information is current as of April 26, 2021

\section{Updated Information \&} Services

References

Subspecialty Collections

Permissions \& Licensing

\section{Reprints}

including high resolution figures, can be found at: http://n.neurology.org/content/97/4/e431.full

This article cites 3 articles, 1 of which you can access for free at: http://n.neurology.org/content/97/4/e431.full\#ref-list-1

This article, along with others on similar topics, appears in the following collection(s):

\section{All Cerebrovascular disease/Stroke}

http://n.neurology.org/cgi/collection/all_cerebrovascular_disease_strok $\mathrm{e}$

CT

http://n.neurology.org/cgi/collection/ct

Embolism

http://n.neurology.org/cgi/collection/embolism

Infarction

http://n.neurology.org/cgi/collection/infarction

Information about reproducing this article in parts (figures,tables) or in its entirety can be found online at:

http://www.neurology.org/about/about_the_journal\#permissions

Information about ordering reprints can be found online:

http://n.neurology.org/subscribers/advertise

Neurology ${ }^{\circledR}$ is the official journal of the American Academy of Neurology. Published continuously since 1951, it is now a weekly with 48 issues per year. Copyright () 2021 American Academy of Neurology. All rights reserved. Print ISSN: 0028-3878. Online ISSN: 1526-632X.

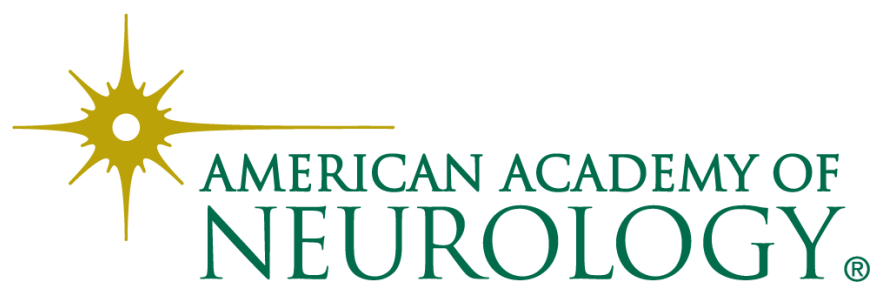

